\title{
The Effect of Corporate Social Responsibility on the Profitability of Nigerian Banks: A Comparative Study of First Bank and Eco Bank
}

\author{
Kehinde Olaide O. and Worlu Rowland E.K \\ Business Management, Covenant University, Nigeria \\ Marketing Department, Covenant University, Nigeria
}

Correspondence should be addressed to: Oluwafeyikemi Kehinde; oluwafeyikemikehinde7@gmail.com

Received date: 31 July 2017; Accepted date: 19 December 2017; Published date: 30 March 2018

Academic Editor: Duncan Momanyi Nyang'ara

Copyright (C) 2018. Kehinde Olaide O. and Worlu Rowland E.K. Distributed under Creative Commons CC-BY 4.0

\begin{abstract}
This study critically examined the effect of corporate social responsibility on the profitability of Nigerian banks using the ECOWAS bank (popularly known as ECO Bank) and First Bank of Nigeria as case studies. The objectives of the study are to: examine the relationship between environmental concerns and return on investment; investigate how corporate governance affects the gross margin of consumer banks; and ascertain whether suppliers' reward improves return on equity of Nigerian consumer banks. The questionnaire was adopted as the instrument for data collection, and the responses derived from the questionnaire were analyzed using simple frequency tables, Pearson correlation, regression analysis and ANOVA test statistics using the Statistical Package for Social Sciences (SPSS) version 23. Findings from this study indicate that corporate social responsibility has a positive influence on the profitability of banks operating in Nigeria, given the institutional deficiencies in the country. It is concluded that an investment into social responsibility positively influences the bank's reputation and image, thereby leading to stronger customer loyalty. It is therefore recommended that banks operating in especially developing countries like Nigeria look beyond financial profit to social profit derived from social responsibility.
\end{abstract}

Keywords: Corporate social responsibility, profitability, consumer banks, environmental concerns.

Cite this Article as: Kehinde Olaide O. and Worlu Rowland E.K (2018), " The Effect of Corporate Social Responsibility on the Profitability of Nigerian Banks: A Comparative Study of First Bank and Eco Bank", Journal of South African Business Research, Vol. 2018 (2018), Article ID 379009, DOI: 10.5171/2018.379009 


\section{Introduction}

The focus of Corporate Social Responsibility in several industries, such as the banking sector, has moved from an effort to be solely ethical to ensuring an ethical performance orientation in all aspects of business operations. Banks have found the need to contribute to the environment of their operations by merging social responsibility to their profitability strategies (Dhaka \& Ullah, 2012). The concept of Corporate Social Responsibility (CSR) is one of the morals and ethics which entails maintaining principled leadership and conduct that create solution to societal issues (Mohammed, Hassan \& Kazi, 2009). Although the major purpose of all commercial banks and generally any business organization is to make profit, there has become a rising recognition of the impact of banking operations on the employees, customers, government, competitors, partners, investors and environment. It is posited that commercial banks should concentrate their consideration on both expanding its main concern and being a decent corporate citizen (Pacific Continental May, 2013; Nurn \& Tang, 2010).

\section{Objectives of the Study}

The broad objective of this study is to explore the effect of Corporate Social Responsibility on the Profitability of the Nigerian banking industry. However, the specific objectives are to;

i. Investigate how corporate governance affects the gross margin of the banks.

ii. Examine the relationship between environmental concerns and return on investments.

iii. Ascertain whether suppliers reward improves the return on equity of a bank.

\section{Research Hypothesis}

\section{Hypothesis one}

$\mathrm{H}_{01:}$ corporate governance practices do not influence banks gross margin.
$\mathrm{H}_{\mathrm{a} 1}$ : corporate governance practices influence banks gross margin.

\section{Hypothesis two}

$\mathrm{H}_{02}$ : there is no relationship between environmental concerns and return on investments.

$\mathrm{H}_{\mathrm{a} 2}$ : there is a relationship between environmental concerns and return on investments.

\section{Hypothesis three}

$\mathrm{H}_{03}$ : suppliers reward does not influence return on equity of a bank in any way.

$\mathrm{H}_{\mathrm{a} 3}$ : suppliers reward influences return on equity of a bank in various ways.

Like all business organizations, consumer banks profit by having revenues in excess of their expenses. The major portion of the bank's profit comes from the fees that it charges for its services and the interest that it earns on its assets, while its major liabilities accrue from the interest paid on its liability (Johansson, Karlsson \& Hagberg, 2015). The issue of corporate social responsibility and its effect to bank profitability is crucial, as it is hypothesized that a successful Corporate Social Responsibility endeavor enhances an organization's reputation, leads to higher productivity and innovation among employees, boosts sales revenue through improved customer goodwill, attracts new customers and balances power with responsibility (Asemah, Okpanachi \& Edegoh, 2013). Based on the above, this study attempts to create a relationship between CSR and profitability in commercial banks by studying the impact of Corporate Social Responsibility (measured using community development, corporate governance, environmental concerns and suppliers rewards) on profitability (measured by sales growth, gross margin, and return on investment and equity).

Kehinde Olaide O. and Worlu Rowland E.K (2018), Journal of South African Business Research, DOI: $10.5171 / 2018.379009$ 


\section{Literature Review}

White (2012) observed that the awareness for CSR is becoming a major cause of concern worldwide, and while several organizations are finding it difficult to deal with this concern, several other organizations are benefiting from the CSR wave. Commercial banks play an important role in the shaping of any economy - developing and developed. In the Nigerian economy, given the direct link between the prosperity of the banking sector and the development of the economy, Nigerian banks are now under more pressure to exhibit responsibility and sustainability (Johansson, Karlsson \& Hagberg, 2015).

Since the establishment of the idea of CSR, there has been a distinctive assessment in the matter of what CSR is proposed to fulfill for a firm. According to Cheng (2014), CSR has the capacity to strengthen the connection between a business organization and its respective stakeholders. It is posited that as an act of being socially responsible, commercial banks can lower their loan constraints through better access to bank credits for small and medium enterprises, thereby contributing to the growth of the economy. In return, the bank is perceived to have the interest of the general populace at heart (Hanke \& Stark, 2009).

\section{The Case Study}

The study reviewed the CSR practices of two consumer banks in Nigeria: First bank of Nigeria and Ecobank. The choice of both banks is as a result of the noticeable CSR practices engaged by both banks in their various branches in the country.

\section{Empirical Framework}

\section{Corporate Social Responsibility Dimensions}

The expansiveness of the concept of corporate social responsibility has created the need to break down the term into sizeable chunks to ensure business organizations are able to fully engage in social responsibility. The triple bottom line concept creates an easy to adopt approach to engaging CSR. It indicates that the concern of the business organization is mainly financial (costs versus pay), such that the business organization is concerned about how it can create value in regards to three different entities: profit, people and planet, commonly referred to as the 3Ps (Dyllick \& Hockerts, 2002). Profit explains how the business organizations (commercial banks in this case) produce economic benefits to the society, in terms of finance. The people aspect of the triple bottom line explains the bank's relationship with its employees, while planet refers to the commercial bank's responsibility to the environment.

In recent literature, the 3Ps have been alluded to as the social, environmental and financial scopes of an organization's CSR execution (Slaper \& Hall, 2011).

\section{Environmental Dimension}

The environmental dimension of the triple bottom line approach to CSR is referred to as the business organization's commitment to reduce the negative environmental impact of its operations. This is usually achieved through appropriately disposing outflows and waste, accomplishing energy effectiveness and efficiency, and generally diminishing practices that may adversely influence the sustainability of natural resources (Yeung, 2011). Rodriquez, Fernandez and Simonetti (2015) highlight the following as the main elements of environmental responsibility:

$\begin{array}{llr}\text { i. } & \begin{array}{l}\text { Adopting environmental } \\ \text { performance measures and } \\ \text { guidelines that are subjected to } \\ \text { international environmental } \\ \text { protection standards. }\end{array} \\ \text { ii. } & \begin{array}{l}\text { Aiding nation-wide } \\ \text { environmental development }\end{array} \\ & \begin{array}{l}\text { goals and initiatives } \\ \text { iii. }\end{array} & \begin{array}{l}\text { Promoting environmental } \\ \text { mindfulness }\end{array}\end{array}$

Kehinde Olaide O. and Worlu Rowland E.K (2018), Journal of South African Business Research, DOI: $10.5171 / 2018.379009$ 

iv. Initiating community-focused discourse on environmental issues.

\section{Social Dimension}

The social dimension views the business organization's relationship with its various stakeholders - consisting dominantly of the shareholders, customers, employees, government bodies and community members. There is a rising pressure for business organizations, especially key entities such as the commercial banks, to give more attention and resources to their relationship with their stakeholders, especially community members, as stakeholders have become more aware of their social rights and do not hesitate in any way to push their social demands on the bank (Dylick \& Hockerts, 2002). It is posited that the bank's main areas of portraying social responsibility from the social dimension perspective, is by ensuring fair employment and labour practices, and by proffering solutions to community challenges, thus creating better social relationship with its stakeholders.

\section{Economic Dimension}

The economic dimension of CSR deals with understanding the economic influences of the bank or company's operations, which entails understanding the firm's impact on the economy, in regards to finances. It indicates how resources for the generation of merchandise and enterprises are conveyed inside the social framework. Several CSR authors such as Carroll (1991) in the pyramid of CSR have inferred that of all dimensions of corporate social responsibility, the economic dimension is the most important. In the case of consumer banks, the economic dimension of CSR goes beyond the banks recording employment figures and debts in their CSR report, but entails core economic issues such as the multiplier effect of the firms' operations, its contributions to the economy through taxes and very importantly, avoiding actions that damage trust (Jucan \& Sabina, 2010).

\section{The Consumer Banks' Cost and Benefits Evaluation of Corporate Social Responsibility}

In the present world system, where consumers place more emphasis on the reputation of a firm than the perception of their products and services, consumer banks have not been left out from this system, as bank managers have begun to incorporate sustainable business practices into their daily operations to fully benefit from good corporate citizenship (Dhaka \& Ullah, 2012).

Investment in corporate social responsibility portrays the bank as one that is interested in people, planet and profit, and not solely its monetary bottom line. This reputation can be very attractive, not just to customers or clients, but also to investors, suppliers, vendors, employees and government. In situations where the employees and other key stakeholders align to this shared values and vision of positive impact, it can lead to better working relationships and increased loyalty, which often results in increased financial gain (Pacific Continental May, 2013). CSR prompts more noteworthy corporate budgetary execution and furthermore encourages the unmistakable benefits of pulling in improved representatives, diminished turnover rate, more significant profitability and decreased working costs. Summarily, the benefits of CSR to the banks include:

i. Higher productivity and innovation among employees.

ii. Increased sales revenue.

iii. Improved customer goodwill.

iv. Ability to attract new customers.

v. Improved balance of power with responsibility.

vi. Enhanced reputation in the workplace (Asemah, Okpanachi \& Edegoh, 2013; Nurn \& Tang, 2010).

Kehinde Olaide O. and Worlu Rowland E.K (2018), Journal of South African Business Research, DOI: $10.5171 / 2018.379009$ 


\section{Theoretical Framework of Corporate Social Responsibility}

The Stakeholders' Theory: Supporting the firm's engagement in CSR practices that encompasses the business organization's relationship with its various stakeholders is the stakeholders' theory, which has for the most part been utilized while examining corporate social responsibility and its effect on the firm's stakeholders. The stakeholders' theory basically engages the concept of how stakeholders should be engaged in the running of the business organizations' operations, such that every decision made in the organization in regards to corporate social responsibility outlines the impact (positive and negative) on the firm's various stakeholders, which usually constitutes of anybody that is affected by the firm's operations, such as the suppliers, customers, employees, and government amongst others (Mitchell, Agle \& wood, 1997).

\section{Methodology}

The descriptive and survey methods of research are adopted in this study. The survey research method is chosen to determine the factors influencing the profitability of Nigerian banks that are engaged in corporate social responsibility. The survey instrument; the questionnaire, is designed using likert categorical scale to measure respondents' attitude towards the important factors of the study. The Sample Size for this study includes all the employees of First Bank and Eco bank in Nigeria.

The sample frame used for this data will be based on convenience sampling. Using the formula postulated by awokemi (2003), we are able to get the sample frame in which the questionnaires would be administered because not everybody in the organization would be reached. The sample frame for this study is Eco bank and First Bank. Since all the population cannot be met, the questionnaires were distributed to the customers and the community.

Due to the inadequate records keeping, the exact number of these employees are not known, but are estimated to be above 10,000. Primary data for this study is collected using the questionnaire, while secondary data is gotten from the Internet, journals and articles. Data gathered from the questionnaire are analyzed using correlation and regression tools of the statistical package for social sciences (SPSS). The Pearson correlation tool is utilized to investigate the quality of connection between two continuous variables and the regression analysis is used to determine the effect of the independent variable on the dependent variable.

The Research validity, questionnaires include a variety of questions on the knowledge of corporate social responsibility and its impact on the profitability of Nigerian banks. The questionnaire is designed in such a way that information gained will provide answers to the research questions and hypothesis. The questions are formulated in simple language for clarity and ease understanding. Clear instructions are given to the respondents. The questionnaires are shared to the employees in Ecobank transactional incorporated and they were all filled in the presence of the researcher. 


\section{Reliability of Research Instruments}

Table 3.1 Reliability
Statistics
\begin{tabular}{|l|l|}
\hline $\begin{array}{l}\text { Cronbach's } \\
\text { Alpha }\end{array}$ & N of Items \\
\hline .727 & 16 \\
\hline
\end{tabular}

A coefficient of 0.727 indicates that the research instrument is reliable, as it is above 0.7 , which is the benchmark for testing reliability.

\section{Corporate Social Responsibility practices of First Bank of Nigeria}

First bank of Nigeria is acclaimed to be one of the leading banks with strong corporate social responsibility practices in Nigeria. Of their numerous community engagements, the following are the most natable ones:

i. The creation of the First bank foundation: The first bank foundation is the unit of the bank that is concerned with the strategising of the bank's corporate social responsibility practices. The aim of creating the foundation was to ensure careful and well thought out engagement between the bank and their customers.

ii. Partnership with several organisations: First bank partners with several organisations to ensure a better societal reach. Such organisations as Cadbury Bournvita, and Alexander Forbes amomg others for several projects. In recent times, they partnered with these organisations to sponsor the 'God's Children Got Talent' program; a talent show for young children, in collaboration with the Redeeemed Christian Church of God province 4.

iii. Investment in educational growth opportunities such as the eregistration forms an initiative for the November/December 2014 West African Senior School Certificate Examination (WASSCE).

iv. Partnership with health care initiatives such as the Sebeccly Cancer Care and Support Centre, to build awareness about cancer, pledge action amongst women to get screened and give access to quality cancer care. FirstBank is also supporting the Centre's Light Lagos Pink Campaign; an annual statewide fundraising campaign to promote breast cancer awareness and raise funds to support breast cancer treatment (First bank foundation, 2017).

\section{Corporate Social Responsibility Practices of Eco Bank}

Just like First Bank of Nigeria, The Ecowas bank (commonly known as Ecobank) is on top of the list of business organisations in Nigeria that have CSR at the fore-front of their operations. Some of the Ecobank's CSR initiatives include:

i. Support for the promotion of education in the country through several initiatives, such as the

Kehinde Olaide O. and Worlu Rowland E.K (2018), Journal of South African Business Research, DOI: $10.5171 / 2018.379009$ 
building of over a 100 seater ultramodern lecture theatre at the Chukwuemeka Odumegwu Ojukwu University (formerly Anambra State University), as part of its corporate social responsibility (CSR) initiatives in 2016. In line with its main startegy of promoting education, Ecobank also committed resources to build classroom blocks for three schools across the country, namely; C\&S primary school, ikorodu Lagos; Government secondary school, Kubwa; Abuja and Eastern academy onistsha, anambra state in 2013.

ii. Ecobank has an Environmental and Sustainability unit within its Group Risk Management department. This unit has the primary responsibility for all environmental and sustainability management, including environmental and social risks, sustainability business development, adoption of green initiatives, energy conservation and carbon footprint management (Ecobank, 2017).

\section{Presentation of Result and Analysis}

The data used here are gotten from the hypotheses tested, which are derived from the research hypotheses listed in the introduction. This study makes use of three sets of hypotheses as seen below:

\section{Test of Hypotheses}

\section{Hypothesis one: The influence of corporate governance practices on banks gross margin}

Table 4.1.1.1 Model Summary

\begin{tabular}{|l|l|l|l|l|}
\hline Model & $\mathrm{R}$ & R Square & $\begin{array}{l}\text { Adjusted } \\
\text { Square }\end{array}$ & $\begin{array}{l}\text { Std. Error of } \\
\text { the Estimate }\end{array}$ \\
\hline 1 & $.234^{\mathrm{a}}$ & .055 & .044 & .60552 \\
\hline
\end{tabular}

a. Predictors: (Constant), Corporate governance has a positive effect on the bank's gross margin

Table 4.1.1.2 ANOVA ${ }^{\mathrm{a}}$

\begin{tabular}{|cc|c|c|c|c|c|}
\hline & Model & $\begin{array}{c}\text { Sum of } \\
\text { Squares }\end{array}$ & $\mathrm{df}$ & Mean Square & $\mathrm{F}$ & Sig. \\
\hline \multirow{2}{*}{1} & Regression & 1.925 & 1 & 1.925 & 5.251 & $.024^{\mathrm{b}}$ \\
& Residual & 33.365 & 91 & .367 & & \\
& Total & 35.290 & 92 & & & \\
\hline
\end{tabular}

a. Dependent Variable: There is a relationship with the bank and its customers

Kehinde Olaide O. and Worlu Rowland E.K (2018), Journal of South African Business Research, DOI: $10.5171 / 2018.379009$ 
b. Predictors: (Constant), Corporate governance has a positive effect on your banks gross margin

Table 4.1.1.3 Coefficients

\begin{tabular}{|c|c|c|c|c|c|}
\hline Model & $\bar{B}$ & $\begin{array}{c}\text { Std.Erro } \\
\mathrm{r}\end{array}$ & Beta & $\mathrm{t}$ & Sig \\
\hline $\begin{array}{c}\text { (constant) } \\
\text { Corporate } \\
\text { governance has a } \\
\text { positive effect on } \\
\text { your banks gross } \\
\text { margin }\end{array}$ & $\begin{array}{l}3.782 \\
.200\end{array}$ & .382 & .234 & $\begin{array}{l}9.909 \\
2.291\end{array}$ & $\begin{array}{l}.000 \\
.024\end{array}$ \\
\hline
\end{tabular}

a. Dependent Variable; There is a relationship with the bank and its customers

Source: Field Survey 2017

Interpretation: At a significance level, which is less than 0.5 , the result shows that corporate governance practices does influence the bank's gross margin. Therefore, the null hypothesis is therefore rejected. The model of the influence of corporate governance explaines the extent to which it influences the gross margin of banks as 5.5\% at 0.024 level of significance where the null hypothesis is rejected.

Kehinde Olaide O. and Worlu Rowland E.K (2018), Journal of South African Business Research, DOI: $10.5171 / 2018.379009$ 
Hypothesis Two: The Relationship Between Environmental Concern And Return On Investment

Table 4.1.2.1 Correlations

\begin{tabular}{|l|l|l|}
\hline & $\begin{array}{l}\text { Has your banks that are } \\
\text { involvement } \\
\text { with the } \\
\text { environment } \\
\text { improved their } \\
\text { returns }\end{array}$ & $\begin{array}{l}\text { their } \\
\text { invironment } \\
\text { tend to have } \\
\text { more return on } \\
\text { their } \\
\text { investment }\end{array}$ \\
\hline $\begin{array}{l}\text { Has your banks involvement Pearson Correlation } \\
\text { with the environment Sig. (2-tailed) } \\
\text { improved their returns }\end{array}$ & 1 & $\begin{array}{l}.206^{*} \\
.048 \\
93\end{array}$ \\
\hline $\begin{array}{l}\text { Banks that are highly Pearson Correlation } \\
\text { involved in their Sig. (2-tailed) } \\
\text { environment tend to have N } \\
\text { more return on their } \\
\text { investment }\end{array}$ & 93 & 1 \\
\hline
\end{tabular}

*. Correlation is significant at the 0.05 level (2-tailed). Source: Field Survey 2017

Interpretation: The relationship between the variables (Banks' involvement with the environment and return on their investment) is examined using Pearson correlation. The result from the test of the relationship between environmental concerns and return on investment shows that (Beta $=0.206, \mathrm{p}<0.01)$. This means that environmental concern has a .206 or $20.6 \%$ relationship with return on investment. The R-square is 0.0424 which amounts to $4.24 \%$ of the variation between environmental concerns and return on investment. It indicates a high relationship between environmental concerns and return on investments. Therefore, the null hypothesis is rejected.

\section{Hypothesis Three: The Influence of Suppliers Reward on Return on Equity}

Table 4.1.3.1 Model Summary

\begin{tabular}{|l|l|l|l|l|}
\hline Model & $\mathrm{R}$ & R Square & $\begin{array}{l}\text { Adjusted } \\
\text { Square }\end{array}$ & $\begin{array}{l}\text { Std. Error of } \\
\text { the Estimate }\end{array}$ \\
\hline 1 & $.438^{\mathrm{a}}$ & .192 & .183 & .44012 \\
\hline
\end{tabular}

a. Predictors: (Constant), An efficient suppliers reward can help a bank increase its ROE

Table 4.1.3.2. ANOVA ${ }^{a}$

\begin{tabular}{|ll|l|l|l|l|l|}
\hline Model & & Sum of Squares & df & Mean Square & F & Sig. \\
\hline 1 & Regression & 4.179 & 1 & 4.179 & 21.576 & $.000^{\mathrm{b}}$ \\
& Residual & 17.627 & 91 & .194 & & \\
& Total & 21.806 & 92 & & & \\
\hline
\end{tabular}

a. Dependent Variable: A rising ROE suggests that a bank is increasing its ability to generate profit.

Kehinde Olaide O. and Worlu Rowland E.K (2018), Journal of South African Business Research, DOI: $10.5171 / 2018.379009$ 
b. Predictors: (Constant), An efficient suppliers reward can help a bank increase its ROE

Table 4.1.3.3 Coefficients

\begin{tabular}{|c|c|c|c|c|c|}
\hline \multirow{2}{*}{ Model } & \multicolumn{2}{|c|}{$\begin{array}{c}\text { Unstandardized } \\
\text { Coefficients }\end{array}$} & $\begin{array}{c}\text { Standardized } \\
\text { Coefficients }\end{array}$ & & \\
\cline { 2 - 4 } & B & Std. Error & Beta & t & Sig. \\
\hline 1 & 2.712 & .336 & & 8.071 & .000 \\
$\begin{array}{c}\text { (Constant) } \\
\text { An efficient suppliers } \\
\text { reward can help a bank } \\
\text { increase its ROE }\end{array}$ & .356 & .077 & .438 & 4.645 & .000 \\
\hline
\end{tabular}

a. $\quad$ Dependent Variable: A rising ROE suggest that a bank is increasing its ability to generate profit

Source: Field Survey 2017

Interpretation: The result from the test of hypothesis three shows that suppliers reward influences return on equity. The model discloses that supplier's reward significantly influences the return on investments of banks at $19.2 \%$ and with a 0.000 level of significance. Therefore, the null hypothesis is rejected.

\subsection{Sustainable Solution Practice Index} for First bank and Eco bank
This section reveals the results of the SSP index of each bank and the results of statistical procedures performed. The sustainable practice index (SSPI) result is derived from each bank and is gotten as follows; SSPI $=$ Total score gotten from the individual banks $\mathrm{x} 100 /$ Total score obtainable.

Table 4.2.1 sustainable solution practice index for First bank and Eco bank

\begin{tabular}{|l|l|l|l|l|l|l|l|l|l|}
\hline S/N & Bank & $\begin{array}{l}\text { Economi } \\
\text { c }\end{array}$ & Social & $\begin{array}{l}\text { Environm } \\
\text { ental }\end{array}$ & General & $\begin{array}{l}\text { SSP } \\
\text { Score }\end{array}$ & $\begin{array}{l}\text { SSPI } \\
\text { index }\end{array}$ & $\begin{array}{l}\text { Interpretatio } \\
\text { n }\end{array}$ & ranking \\
\hline 1 & $\begin{array}{l}\text { First } \\
\text { bank }\end{array}$ & 5 & 8 & 0 & 3 & 16 & 80 & substantial & $1^{\text {st }}$ \\
\hline 2 & $\begin{array}{l}\text { Eco } \\
\text { bank }\end{array}$ & 2 & 2 & 3 & 2 & 10 & 50 & High & $2^{\text {nd }}$ \\
\hline
\end{tabular}

Source: Published accounts of the selected banks based on their CSR practices 2014

Interpretation: - The results above show that First Bank had the highest SSP score index of 80 , which is considered to be substantial. Eco bank has a high SSP score as well because they are presently no accounting principles in Nigeria on sustainability reports. The result shows that the banks are mostly involved in social responsibility with a score of 12 over the total score 31 representing (39\%). The economic responsibility amounts to a score of 9 over the total 31 representing (29\%). The general responsibility amounts to a score of 5 over the total 31 representing $(16 \%)$ and the environmental responsibility amounts to a score of 4 over the total 31 representing (13\%). Overall the four sustainability practices are well represented.

Kehinde Olaide O. and Worlu Rowland E.K (2018), Journal of South African Business Research, DOI: $10.5171 / 2018.379009$ 
Table 4.2.2 Corporate Social Responsibility expenditure of First bank

\begin{tabular}{|l|l|l|}
\hline \multicolumn{3}{|l|}{ First Bank of Nigeria Plc } \\
\hline & $\begin{array}{l}\text { CSR } \\
\text { Year }\end{array}$ & $\begin{array}{l}\text { Profit After } \\
\text { Tax } \\
\text { N’ 000 }\end{array}$ \\
\hline Column 1 & Column 2 & Column 3 \\
\hline 2006 & $119,887,000$ & $32,164,000$ \\
\hline 2007 & $315,883,000$ & $36,679,000$ \\
\hline 2008 & $438,729,000$ & $12,569,000$ \\
\hline 2009 & $1,229,513.82$ & $3,622,000$ \\
\hline 2010 & $887,743.64$ & $29,170,000$ \\
\hline 2011 & $904,136.12$ & $44,785,000$ \\
\hline 2012 & $924,613.81$ & $46,124,000$ \\
\hline 2013 & $552,700,000$ & $31,238,627$ \\
\hline 2014 & $849,256,000$ & $11,940,000$ \\
\hline 2015 & $59,460,000$ & $43,175,435$ \\
\hline 2016 & $734,654,400$ & $55,735,220$ \\
\hline
\end{tabular}

\section{First Bank CSR and PAT}

$900,000,000$

$800,000,000$

$700,000,000$

$600,000,000$

$500,000,000$

$400,000,000$

$300,000,000$

$200,000,000$

$100,000,000$

\section{0}

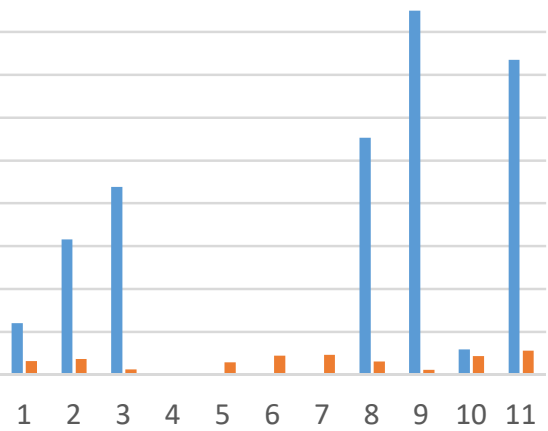

- Column 2 Column 1

Fig 1.A Chart showing the value of first Banks contribution to Corporate Social Responsibility

Kehinde Olaide O. and Worlu Rowland E.K (2018), Journal of South African Business Research, DOI: $10.5171 / 2018.379009$ 
Table 4.2.3 Corporate Social Responsibility expenditure of EcoBank

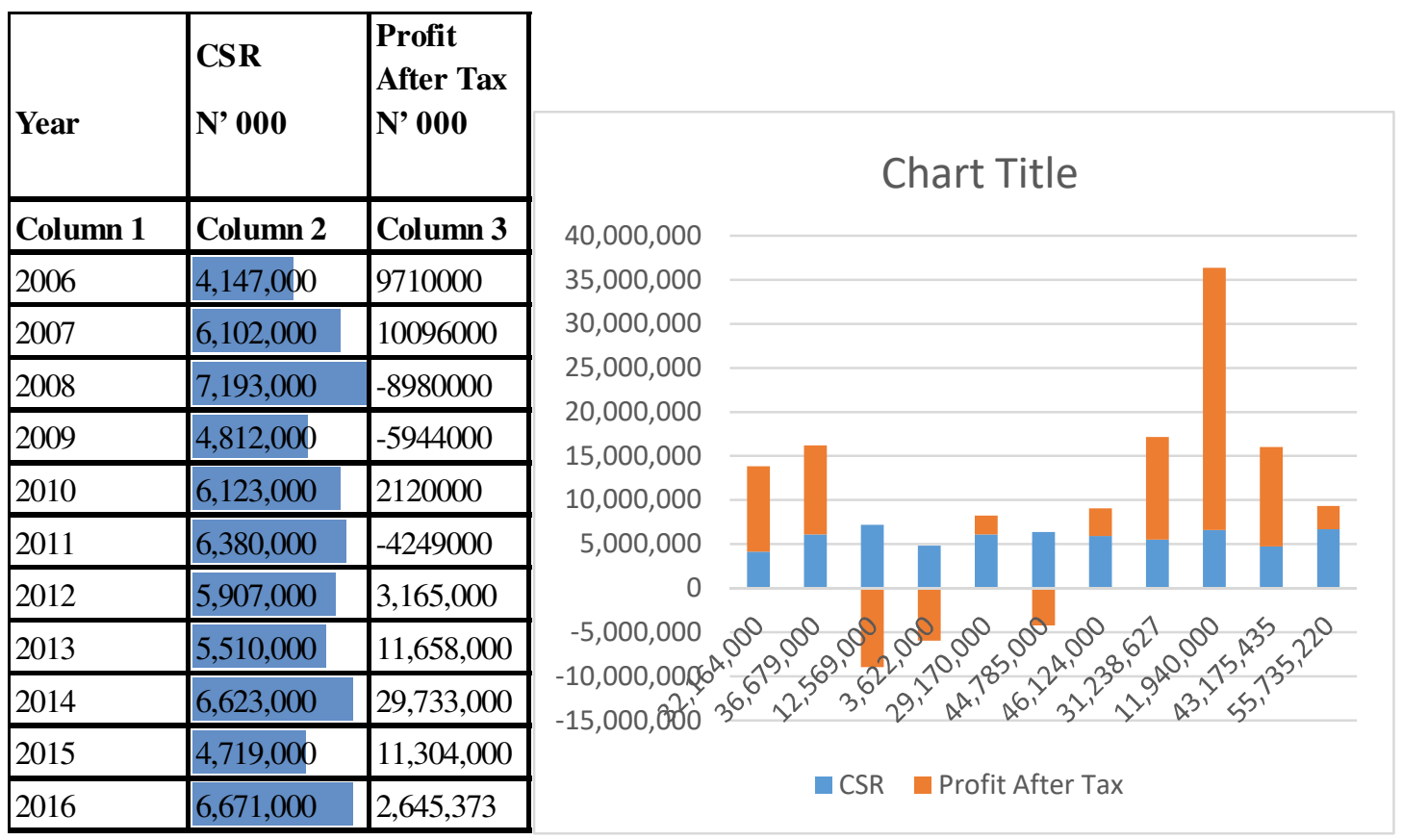

Fig 2: A Chart showing the value of EcoBanks contribution

to Corporate Social Responsibility

Source: Published Annual Reports of the Selected banks from 2006-2016

Interpretation: - This research study shows that First Bank Plc has the highest corporate social responsibility expenditure of N1,229,513,816 in year 2009, while Eco Bank has the lowest CSR expenditure of $\mathrm{N} 4,147,000$ in year 2006. This means that first bank is the leading commercial bank when it comes to CSR and it reveals that there is a significant relationship between corporate social responsibility on expenditure and profitability. First bank has always been contributing large donations to their CSR practices and it shows in their profitability, as they make bigger profits each year. Eco bank puts in smaller amount of money or donations to their CSR practices and it also shows that the bank does not make profit all the time, as they were making loss in the year 2008-2011. Although CSR brings about a decline in the profit after tax, it also encourages more involvement which leads to profit. Therefore, contributing to CSR improves the sustainability part of the banks financial statement which includes social responsibility. It should be noted that the banks have responsibility to several group of a company's investors both internal and external.

\section{Summary of Findings}

The research findings are divided into two namely; theoretical findings and empirical findings.

\section{Theoretical Findings}

The stakeholder theory identifies the business actions and decisions that must be taken into consideration towards the shareholders, managers, community, customers and employees. Shareholders and

Kehinde Olaide O. and Worlu Rowland E.K (2018), Journal of South African Business Research, DOI: $10.5171 / 2018.379009$ 
investors are one of the major stakeholders in the business and they are directly affected by decisions taken by the business. CSR is a reflection of stakeholders' theory in regards to business actions and how it affects their profitability. In order for a business to be sustainable in the long run, they need to consider the environment as a major decision making point. Newton (2014) said that the key to CSR is trust, and an economic driver of a business is its corporate image, which is what investors and shareholders look at, and maintaining it should be an ethical priority.

\section{Empirical Findings}

The empirical findings which are based on the analyzed objectives, specify the following:

\section{The Role of Community Development in} Enhancing the Sales Growth of the Bank

The empirical findings based on this objective are stated as follows

i. Banks involvement in community development can enhance their sales growth.

ii. Banks non- involvement in community development can affect their sales growth positively.

iii. Most banks are involved in community development.

iv. Banks have gained more customers through community development.

\section{Corporate Governance Practices Affect the Gross Margin of the Bank}

The empirical findings based on this objective are stated as follows

i. Corporate governance has appositive effect on their banks gross margin.

ii. Banks have a relationship with their customers.

iii. The principles and regulations put in place by the bank have improved the gross margin ratio. iv. The policies in the bank are in the favour of the customers.

\section{The Relationship between Environmental Concern and Return on Investment}

The empirical findings based on this objective are stated as follows

i. The banks involvement with the environment improves their returns.

ii. In the long run, the bank gains more customer loyalty because of their involvement in the environment.

iii. The banks that are highly involved in their environment tend to have more return on their investment.

iv. The banks have improved the welfare and environment in which they are located in.

\section{Suppliers' Reward Improves the Return on Equity}

The empirical findings based on this objective are stated as follows

i. An efficient supplier's reward can help a bank increase its return on equity.

ii. A rising return on equity suggests that a bank is increasing its ability to generate profit.

iii. The growth and profitability of banks are better optimized through information, financial and physical suppliers reward.

iv. A bank's return on assets can increase, if their supply chain is as good as the relationship with suppliers.

\section{Conclusion and Recommendations}

This research concludes that corporate social responsibility has a strong positive effect on the profitability of consumer banks in Nigeria. It is observed that banks in Nigeria gain such benefits because of the improved reputation and image, enhanced customer loyalty and ultimately improved profitability when they align their operations with social

Kehinde Olaide O. and Worlu Rowland E.K (2018), Journal of South African Business Research, DOI: $10.5171 / 2018.379009$ 
responsibility in the aspect of their relationship with their various stakeholders. Based on the above conclusion, it is recommended that commercial banks engage active CSR practices with their various stakeholders; banks should also make it a priority to include their stakeholders in their decision making. Also banks should be prompt in handling ethical issues involving their transactions and activities, and should be very transparent in their dealings with the public, if they intend to be sustainable. On the part of the government, policies and duties concerning CSR practices for commercial banks should be clearly outlined and enforced. Summarily, the relationship between corporate social responsibility and organisational profitability cannot be over emphasized, as such managers, scholars, government and other stakeholders should invest resources into unravelling the concept.

\section{References}

1. Harward \& Upton (1961), 'Introduction to Business Finance', Mc Graw Hill, New York.

2. Johansson, S., Karlsson, A. and Hagberg, C. (2015), 'The Relationship Between CSR and Financial Performance; A quantitative study examining Swedish publicly traded companies'. Linnaeus University, Sweden.

3. Jucan, CN and Jucan, MS. (2010), 'Dimensions and Challenges of Social Research', Annales Universitatis Apulensis series Oeconomica, 12(1).

4. Mipur, D., and Shadid, U. (2012), 'Banks play a leading role in CSR', vol. 20, no. 235, http://www.printthefinancialexpress.bd.com

5. Mitchell, R., Agle, B. and Wood, D. (1997), 'Toward a Theory of Stakeholder Identification and Salience: Defining the Principle of Who and What Really Counts', The Academy of Management Review, 22 (4), pp. 853-886

6. Mohammed, BU., Hassan, Md. R. and Kazi, Md. T. (2008) 'Three dimensional aspects of corporate social responsibility', international universal journal of business and economics, vol. 3 , no. 1, pp. 200-212

7. Nurn, CW., and Tan, G. (2010), 'Obtaining intangible and tangible benefits from corporate social responsibility', International Review of Business Research Paper, Vol. 6(4), Pp. $360-371$

8. Pacific Continental (2013), 'White paper importance of corporate social responsibility'.

9. Pandey I.M (2002), 'Financial Management', New Delhi, Vikas Publishing House Pvt. Ltd.

10.Shirley Yeung (2011), 'The Role of Banks in Corporate Social Responsibility', Hang Seng School of Management, China. Journal of applied economics and business research, JABER 1(2), pp. 103-115.

11.Thomas Dyllick and Kai Hockerts (2002), 'Beyond the business face for corporate sustainability', business strategy and the environment, vol. 11, pp. 130-141, doi:10:1002/bse.323

12.Van Marrewijk, K., \& Verre. (2003), 'Concepts and definition of CSR and corporate sustainability: Between agency and communion', Journal of business ethics, 44(2-3): 95-105.

13.William Bentum (2012), 'The determinants of profitability of the commercial banks in Ghana during the recent years of global financial crisis', Aarhus school of business, Aarhus University

Kehinde Olaide O. and Worlu Rowland E.K (2018), Journal of South African Business Research, DOI: $10.5171 / 2018.379009$ 